\title{
Contamination of Device Ingredient or Reagent
}

National Cancer Institute

\section{Source}

National Cancer Institute. Contamination of Device Ingredient or Reagent. NCI

Thesaurus. Code C63266.

Problem associated with the undesired introduction of impurities either chemical or microbiological in nature, or of foreign matter into or onto the device ing redient or reagent. 